\title{
Undocumented People (En)Counter Border Policing
}

\author{
Near and Far from the US Border
}

\author{
Denise Brennan
}

\begin{abstract}
This article examines undocumented people's everyday lived experience in the United States where their legal status is criminalized. It asks how they live with constant threat and surveillance. It highlights their strategies of invisibility as well as their generous contributions to their communities. It argues that these acts of "community caretaking" are acts of "hospitality" that demonstrate their "good citizenship." Every time undocumented people conduct "know your rights" workshops, they model citizenship in action. The article also explores the other side of the daily equation to stay safe and spotlights undocumented people's encounters with law enforcement agents. Agents do not act in lockstep, but rather make decisions in split seconds that can change undocumented people's lives forever. Drawing from ethnographic field research in migrant communities inside the "100-mile border zone" as well as deep in the US interior, the article argues that "border policing" happens far from the border.
\end{abstract}

KEYWORDS: border zone, migration, racial profiling, undocumented, United States

Whether living along the border or deep within the US interior, undocumented people know that their lives could be upended by a traffic stop or by employers, landlords, or partners blowing the whistle on their legal status. The border may not be everywhere, but its policing is. Over three million individuals were deported from the United States during President Obama's two terms, prompting the migrant rights community to refer to him as the "Deporter-in-Chief." President Trump has taken policing to a new level by making all undocumented migrants a "priority" for deportation. Every undocumented adult and child is now a walking target. US Immigration and Customs Enforcement (ICE) agents have already made 65,000 arrests since the inauguration-a $40 \%$ increase since this time last year (The White House 2017). The president has vowed to continue this deportation spree in order to forcibly remove over 11 million people.

For this inaugural edition of Migration and Society with the theme of hospitality and hostility, this article offers reflections from ongoing ethnographic field research throughout the United States with undocumented people on the lived experience of being "wanted." The ethnographic project calls attention to how undocumented people confront state surveillance and criminalization with tactics to live undetected. At the same time that they avoid the attention of law enforcement, undocumented people, however, are far from hiding. Under assault, they try to live apart from the nation's security state while they live as part of vibrant communities. My ongoing field research highlights the tension between this simultaneous invisibility and obvious presence of undocumented persons throughout the country. ${ }^{1}$ 
This article focuses, in particular, on encounters with law enforcement in a legal system that criminalizes immigration. Since many of these encounters begin with racial profiling, the article uses Orisanmi Burton's assertion that policing in the United States is "always already about racialized policing" whose function is "to protect and serve whiteness," as a frame through which to read the stories below about racial profiling of undocumented people (Burton 2015: 38-39). ${ }^{2}$ I also turn to Didier Fassin's research on how state agents learn to implement the law. The deportation regime is comprised of individual state agents who interpret what Fassin aptly describes as the "diverse rationalities" of the state. We see the everyday workings of the state through "what its agents do under the multiple influences of the policies they implement, the habits they develop, the initiatives they take, and the responses they get from publics" (Fassin 2015: ix). In so doing, these state agents make the state visible as they exercise a tremendous degree of power.

This research project on everyday life without documentation grows out of my previous book that follows the first recipients of trafficking visas to remain in the United States (Brennan 2014). What is largely unknown about trafficking in the United States is that a paltry number of trafficking visas have been issued to date. ${ }^{3}$ This low number is inextricably tied to the racial profiling of people assumed to be undocumented. I argue that this form of immigration relief for migrants who have been so severely exploited that they qualify as trafficked has been underutilized in part because law enforcement are not screening for trafficking. The key argument in this article is that law enforcement agents' biases, perceptions, and actions when they encounter migrants shape how they exercise the immense discretion they have in these moments of determination. ${ }^{4}$ When law enforcement agents encounter individuals who they believe might not have documentation, they decide, often in split seconds, whether, for example, to issue a ticket for driving without a license or to pull in the firepower of the federal government and alert Border Patrol or ICE. They also have the authority to decide whether to proceed with a trafficking screening. These moments of determination can put undocumented migrants on a path towards immigration relief or towards deportation. Agents' decisions made in the heat of the moment affect people's lives forever.

Attacks on migrant communities cannot be viewed in isolation from attacks on communities of color through violent policing and mass incarceration (Alexander 2010; Browne 2015; Rios 2011). Immigrant enforcement policies have dramatically shaped daily life in migrant communities. Nearly one quarter of Latinos in the United States personally know someone who has been detained or deported (Hugo Lopez 2011). As sociologist Douglas Massey has observed, it is the first time since the Civil War that so many people have so few rights (Massey 2017).

\section{Methodology}

Over the past three years I have interviewed undocumented individuals-or members of mixed status families-who live in interior communities (in New York, Maryland, Washington, DC, Virginia, North Carolina, Texas, California, and Oregon) as well as in southern and northern border communities (New York, Florida, Alabama, Texas, Arizona, California) inside the "100mile border zone," an enhanced immigration enforcement zone that spans the entire periphery of the United States (American Civil Liberties Union [ACLU] 2015). Those living inside the 100-mile border zone experience particularly intense surveillance and policing. Border Patrol checkpoints (usually over 30 miles from the actual border) on roads out of southern and northern border communities make travel further into the interior of the United States risky for undocumented people. As a result, community leaders inside the 100-mile border zone report high rates of workplace exploitation, domestic abuse, unwanted pregnancies, and untreated ill- 
nesses because of restricted mobility (Griffin et al. 2014; Heyman 2016; Montalvo-Liendo et al. 2009; Queally 2017; Sacchetti 2017; Salcido and Adelman 2004). ${ }^{6}$

This ethnographic field research forms the basis for a book I am currently writing, Undocumented: Criminalizing Everyday Life in the United States. The book also draws from interviews with community organizers, attorneys, social workers, domestic violence counselors, medical professionals, teachers, school counselors, and faith leaders. And I have sought out interviews with individuals who witness first hand the workings of the deportation regime as well as the deep roots of undocumented people's lives in the United States. For example, I have interviewed grocery store owners about police and ICE arrests outside their store fronts; women who sell food out of the back of their vehicles to undocumented farmworkers who fear driving to get provisions; medical professionals who find creative ways to help undocumented patients (or parents of sick children) access specialized care beyond interior Border Patrol checkpoints; faith leaders in the Sanctuary movement; hotline operators who field calls from families looking for loved ones who set out on the migrant trail; ranchers whose property is on the migrant trail; Border Patrol agents and their spouses; and young people in mixed status families who grew up crossing the border for school.

In addition to formal interviews, I have been in a variety of spaces where migrant leaders have exchanged knowledge, offered support, strategized, and fought for justice. I have attended rights workshops and empowerment meetings with domestic worker, farmworker, and day labor organizers; domestic violence survivors; youth leaders; and leaders in the LGBTQ community. In these settings, I explore everyday transactions that documented individuals take for granted but which become exceedingly risky or challenging for undocumented people. Although I have interviewed undocumented people who are from all over the world, the bulk of my field research has been with individuals originally from Latin America, since they comprise over 96\% of deportations.

\section{Individual Law Enforcement Agents' Decision-Making}

When examining examples of individual law enforcement officers' decisions in encounters with undocumented people, it is clear that the agents do not act in lockstep. As Didier Fassin reminds us, the state "is more than a bureaucracy with rules and procedures." Rather, a range of personal values, professional principles, and public debates "influence what the agents think and do." As they make decisions at the "microsocial level," we see "moral subjectivities" at work (Fassin 2015: x). An undocumented activist in Los Angeles recounts being in the back seat of her aunt Carmen's van when a police officer pulled them over and asked for her aunt's license. Seeing a baby and an elementary school-aged child (the activist) in the back seat, the police officer made the decision to give Carmen a ticket and impound the car, all the while yelling at Carmen (in Spanish) for risking driving. After handing the officer her car keys, Carmen grabbed the dozens of cupcakes they had baked for a school fundraiser and walked the rest of the way to school with her niece and the baby in her car seat. Later, she realized she had forgotten to take her bed-ridden son's specialized wheelchair out of the trunk. Too afraid to retrieve the car-and the wheelchair-Carmen instead made the calculation to begin saving to replace them both.

In the Rio Grande Valley in Texas, Alma tells of getting stopped by a local police officer who claimed she had run a red light. When she could not produce a driver's license at his request, she explained that she was on her way to take her son, who has autism, to see a spe- 
cialist. Like the police officer in Los Angeles, this officer made the decision to issue a ticket for driving without a license and to not run her fingerprints through the federal database to see if she was undocumented. Instead, he impounded the car. Alma and her son waited at a Stripes gas station for a documented friend to pick them up. This police encounter could have ended differently: with Alma in the back of the officer's vehicle and her friend taking her son home. Following this encounter, Alma was shaken up. Terrified of being separated from her children, she and her husband adopted what I refer to as "border improvisations" to reduce the likelihood of run-ins with the police. Alma no longer travels for specialized medical care for her son, and she has stopped going to English-language classes in a nearby town. "I can't risk getting stopped again. What would my son do without me?" Her husband has also significantly altered his daily routine. Ever since President Trump was elected, he has been staying on the ranch where he works during the week, instead of driving back and forth every day. Staying off the road as much as possible, he has been trying to minimize his exposure to driving-related police encounters.

The trade-offs are not easy. Alma single-handedly takes care of their six young children. When Border Patrol agents park at the only entrance and exit to their colonia (unincorporated neighborhood), she asks documented neighbors to pick up a few items for her at the supermarket. Essentially a blockade, residents in colonias are trapped when Border Patrol agents decide to monitor all traffic into and out of their neighborhood. "We are in lockdown," explains another mother in a nearby colonia. "No one can get to work or school." Since the election, many undocumented members of the community talk of not driving at night, when law enforcement can allege that they are driving without head or tail lights. Explaining how the election changed daily choices and rhythms, an organizer said: "If you run out of milk at night, your children don't have milk with dinner." Her improvisation is simple: she stays off the road.

The police know which residential communities have a high concentration of unauthorized individuals. By driving through them regularly, parking, and setting up checkpoints, they intimidate and create a chronic sense of fear and insecurity. These checkpoints have been happening for years, before President Trump was elected. Staff at a Spanish-speaking community-based organization in Winston Salem, North Carolina, for example, described periodic police checkpoints (while President Obama was in office) at the entrance to a neighborhood comprised mainly of Latino residents. When checkpoints go up, residents cannot enter or exit their neighborhood without speaking to the police officers. A young mother whose parents are undocumented described "worry(ing) every day" since her mother and father have to drive to get to work. "Anything can happen." With President Trump in office, her mother now does not leave the house without first checking Facebook to see if there are any posts about police or ICE activity. She also signed up for PaseLaVoz, a free service that sends text alerts about police activity. These safety plans are essential in towns like Winston Salem where, as the organizer describes, police checkpoints go up a block from a Spanish-speaking mass, or near a quinceañera at a restaurant or a barbecue in the park.

\section{Challenging State Surveillance and Violence}

Israel's encounter with a Border Patrol agent in a sleepy beach town on the outskirts of Jacksonville, Florida captures not only how state agents make choices but also resistance to racialized policing and a rejection of the criminalization of migrants. A successful businessman, Israel runs his own construction firm and employs over a dozen workers. His large gleaming red 
pickup truck and three white vans are signs of his financial security and business acumen. His collision with Border Patrol began when an agent drove up alongside one of Israel's white vans. The agent signaled for Israel to pull over. He overheard Israel tell his three employees (in Spanish) to not say anything. It is at this point that the agent "heated up" and the situation escalated quickly. Israel explained: 'He got red in the face. He kept on asking me for 'ID' - but he didn't want the driver's license I handed him. He wanted some form of Mexican ID." Incensed by the valid license, the agent then opened the van door and put handcuffs on Israel's left wrist. These two men in control of their worlds tussled-first verbally and then physically. The agent said what was on his mind: "I know you are an immigrant." Israel tried to talk him down, as if "we were in line together at the grocery store," offering: "I don't know what you are talking about because we are all immigrants." In a rage, the agent then tried to pull Israel out of the van by yanking his arm, banging his cuffed arm against the van door multiple times. Israel bled all over them both. Unknown to the agent, Israel had been filming the event on his phone the whole time. Later, when the agent realized he had been recorded, he told Israel, "I hadn't given consent for you to film me." To which Israel replied, "I didn't give consent to be in your car."

Israel insisted on naming the agent-Edwin-and requested that I use the agent's real name as well. In so doing, he underscores Fassin's point that state agents are not faceless interpreters and enforcers of the law and state power. In fact, Edwin made assumptions when he first saw the van, and then took action. Israel explains: "Border Patrol immediately chase when they see white vans. Look at the way he pulled me over. He was in the fast lane. Border Patrol does this. They immediately chase when they see white vans." In a soft measured voice, he calmly observed that the local police do the same. "They regularly stop Hispanos. And then they call Border Patrol." Just a week earlier, the police had stopped a documented friend of Israel's who also had been driving a white van. He too understood the hunt for what it was. But he and his undocumented co-workers were ready for this possible scenario. They saw the police vehicle following them. "My friend told his buddies, 'If they put their lights on, you guys run."' When the police did stop the van, Israel's friend stayed in the van while his friends ran off.

These orchestrated dragnets often yield a random group of individuals to send to detention. Once profiled, Israel landed in detention for three weeks. ${ }^{7} \mathrm{He}$ and his wife concocted a cover story to tell their three children - that Israel was working on a job site out of state. "They are used to me coming home every day. They still don't know what happened." Despite Israel's calm logic in the face of racial profiling, fury, and abuse, whether families like his can stay living under the same roof hinges on law enforcement officers' whims, temperament, and ability to control their anger. Israel has had other interactions with officers who, in sharp contrast, decided to use their authority to help the community. A highway patrol officer pulled him over, for example, to let him know that a ladder was about to fall off his van's roof.

In Jacksonville I also met Juan, who is close to securing his papers through marriage. On an out-of-state construction job in Georgia, a police officer ran Juan's plates while he was pumping gas. Like Israel, he confronted the officer and asked why he singled him out when he was simply filling his gas tank. The police officer told him: "Because no one drives in my county without a driver's license." (Juan did have a valid driver's license at the time.) The officer took him to the local police station where the front desk officer warned, "You are going in and not coming out."

Despite multiple run-ins with law enforcement, Juan refused to limit his job choices or his mobility. "There are many Border Patrol around here. We have no choice but to see them all the time. I can't hide and live like a criminal. Stuff like this happens all the time. We have no rights." He continued, "Sometimes I get depressed and paralyzed by fear." If his paperwork does not come through, he will leave the United States. "If I have to go back, I want it to be on my own. Rather than get sent back. They treat you like animals." 


\section{Conclusion}

Edwin's decision to stop Israel, much like the police officer's decision to stop Juan-as well as the officer's decision to impound Carmen's car in Los Angeles and the Rio Grande Valley officer's decision to do the same to Alma's car-demonstrates how state agents strategically use their power to hunt for people who they assume do not have authorization. These calculated arrests, which are made possible through rampant and unchecked racial profiling, help account for the record-high levels of deportation. "Arrests happen all the time," Israel said. "We hear about ICE knocking on doors and taking people out-often not the person they were looking for. They just go looking for people." These experiences with racial profiling and abuse of power echo what I have heard in communities throughout the United States, not just in border communities. As a lawyer in northern Virginia laid out, "Look, they get who they get. There is always room in the back of the van."

DENISE BRENNAN is an anthropologist who writes about migration, trafficking, and labor. She is Professor and Chair of the Department of Anthropology at Georgetown University. Her most recent book, Life Interrupted: Trafficking into Forced Labor in the United States (Duke University Press, 2014), follows the lives of the first trafficking survivors in the United States. She is currently conducting research on life without documentation in the United States for a new book, Undocumented: Criminalizing Everyday Life in the United States.

\section{NOTES}

1. Over half of undocumented adults have citizen children and have lived in the United States for more than 10 years (Center for American Progress 2017). The United States is their home. As the protest chant proclaims, undocumented migrants are "here to stay."

2. Today's immigration enforcement continues a long history of racial profiling and discrimination in the United States (Bayoumi 2009; Bonilla-Silva 2003; Cacho 2012; Hernández 2010), particularly a history of arresting and forcibly removing individuals assumed to be born outside of the US-such as the internment of Japanese-Americans and "Operation Wetback" in the 1950s (Hahamovitch 2011; Kanstroom 2007; Moloney 2012; Ngai 2004).

3. Even though the law, the Trafficking Victims Protection Act (TVPA), allows up to 5,000 T visas to be issued each year, fewer than 10,000 have been given out since the passage of the legislation in 2000 . Since the US government estimates that between 14,500 and 17,500 individuals are in situations of trafficking, it is clear that efforts to look for and protect exploited migrant workers have fallen short (Brennan 2014, 2017).

4. Writing about the "enormous" discretion that law enforcement agents exercise, legal scholar Dina Haynes worries about the inadequate training on how to use "the power that comes with that discretion" (Haynes 2007: 370). Two of the first attorneys in the US to work with trafficking survivors, Kathleen Kim and Charles Song, also find that "bias" is at play-shaped by labor sector and genderwhen law enforcement determines "who counts as a victim and who does not" (Kim et al. 2009: 44).

5. The ACLU's map of the border zone shows how many people live inside this "border zone": https:// www.aclu.org/know-your-rights-governments-100-mile-border-zone-map.

6. Border communities in the Rio Grande Valley, for example, are among the most "medically underserved areas in the nation" with gaps in "public health services, poor access to care, significant health effects of environmental factors (water treatment, pollution, crowding) and high rates of chronic disease" (Castañeda 2015: 109). 
7. Luckily, Israel and his wife were working with an attorney at a university's immigration clinic to secure a $U$ visa for his wife (her previous husband had abused her). This attorney secured bail$\$ 2500$ - and Israel, unlike many who are profiled and jailed, had the money in the bank. The case is ongoing since Israel filed a case of abuse against Edwin.

\section{REFERENCES}

Alexander, Michelle. 2010. The New Jim Crow: Mass Incarceration in the Age of Colorblindness. New York: The New Press.

American Civil Liberties Union (ACLU). 2015. "Fact Sheet on Customs and Border Protection's (CBP's) 100-Mile Rule." https://www.aclu.org/sites/default/files/field_document/14_9_15_cbp_100-mile_ rule_final.pdf.

Bayoumi, Moustafa. 2009. How Does It Feel to Be a Problem? Being Young and Arab in America. New York: The Penguin Press.

Bonilla-Silva, Eduardo. 2003. Racism without Racists. Lanham, MD: Rowman \& Littlefield.

Brennan, Denise. 2014. Life Interrupted: Trafficking into Forced Labor in the United States. Durham, NC: Duke University Press.

Brennan, Denise. 2017. "Fighting Human Trafficking Today: Moral Panics, Zombie Data, and the Seduction of Rescue." Wake Forest Law Review 52 (2): 477-496.

Browne, Simone. 2015. Dark Matters: On the Surveillance of Blackness. Durham, NC: Duke University Press.

Burton, Orisanmi. 2015. “To Protect and Serve Whiteness." North American Dialogue 18 (2): 38-50.

Cacho, Lisa Marie. 2012. Social Death: Racialized Righteousness and the Criminalization of the Unprotected. New York: New York University Press.

Center for American Progress. 2017. “The Facts on Immigration Today: 2017 Edition." https://www .americanprogress.org/issues/immigration/reports/2017/04/20/430736/facts-immigration-today2017-edition/.

Castañeda, Heide. 2015. "Mixed-Status Families in the Rio Grande Valley of Texas: Health Disparities and Life along the US/Mexico Border." In Living Together, Living Apart: Mixed Status Families and US Immigration Policy, ed. April Schueths and Jodie Lawston, 106-118. Seattle: University of Washington Press.

Fassin, Didier. 2015. “Preface: Can States Be Moral?” In At the Heart of the State: The Moral World of Institution, ed. Didier Fassin, ix-xi. London: Pluto Press.

Griffin, Marsha, Minnette Son, and Eliot Shapleigh. 2014. “Children's Lives on the Border." Pediatrics 133 (5): e1118-e1120.

Hahamovitch, Cindy. 2011. No Man's Land: Jamaican Guestworkers in America and the Global History of Deportable Labor. Princeton, NJ: Princeton University Press.

Haynes, Dina. 2007. "(Not) Found Chained to a Bed in a Brothel: Conceptual, Legal, and Procedural Failures to Fulfill the Promise of the Trafficking Victims Protection Act." Georgetown Immigration Law Journal (21): 337-382.

Hernández, Kelly Lytle. 2010. Migra! A History of the US Border Patrol. Berkeley: University of California Press.

Heyman, Josiah McC. 2016. "Unequal Relationships between Unauthorized Migrants and the Wider Society: Production, Reproduction, Mobility, and Risk." Anthropology of Work Review 37 (1): 44-48.

Hugo Lopez, Mark et al. 2011. "As Deportations Rise to Record Levels, Most Latinos Oppose Obama’s Policy." Pew Hispanic Research Center. December 28.

Kanstroom, Daniel. 2007. Deportation Nation: Outsiders in American History. Cambridge, MA: Harvard University Press.

Kim, Kathleen C., Charles Song, and Srividya Panchalam. 2009. "Conversation with Two Anti-Trafficking Advocates: Kathleen Kim and Charles Song, Reported by Srividya Panchalam.” Los Angeles Public Interest Law Journal 1: 31-64. 
Massey, Douglas. 2017. "America's Immigration Policy Fiasco." Presentation at the Institute for the Study of International Migration, Georgetown University, Washington, DC, 29 March.

Moloney, Deirdre M. 2012. National Insecurities: Immigrants and US Deportation Policy since 1882. Chapel Hill: University of North Carolina Press.

Montalvo-Liendo N., D. W. Wardell, J. Engebretson, and B. M. Reininger. 2009. "Factors Influencing Disclosure of Abuse by Women of Mexican Descent." Journal of Nursing Scholarship 41 (4): 359-367.

Ngai, Mae M. 2004. Impossible Subjects: Illegal Aliens and the Making of Modern America. Princeton, NJ: Princeton University Press.

Queally, James. 2017. "Fearing Deportation, Many Domestic Violence Victims Are Steering Clear of Police and Courts." Los Angeles Times, 9 October.

Rios, Victor M. 2011. Punished: Policing the Lives of Black and Latino Boys. New York: New York University Press.

Sacchetti, Maria. 2017. "A Girl with Cerebral Palsy is Being Held in Immigration Detention: The ACLU Just Sued for Her Release." Washington Post, 31 October.

Salcido, Olivia, and Madelaine Adelman. 2004. "He Has Me Tied with the Blessed and Damned Papers': Undocumented-Immigrant Battered Women in Phoenix, Arizona." Human Organization 63 (2): 162-172.

The White House. 2017. "Press Gaggle by Director of Immigration and Customs Enforcement Tom Homan, US Attorney for the State of Utah John Huber, and Principal Deputy Press Secretary Sarah Sanders." Press Release. https://www.whitehouse.gov/the-press-office/2017/06/28/press-gaggledirector-immigration-and-customs-enforcement-tom-homan-us (accessed 1 November 2017). 